Beata Zagozdzon

\title{
CONDITIONS FOR THE DEVELOPMENT OF PUBLIC-PRIVATE PARTNERSHIP PPP = ANALISIS BASED ON AN EXAMPLE OF TRANSPORT INFRASTRUCTURE IN POLAND
}

Transport infrastructure is not currently the domain of activity of solely the public sector. Governments entrust the provision of services or realization of investment tasks to private entities and the form of involvement of private investors may be the public-private partnership PPP. Successful implementation of the PPP projects requires appropriate economic, legal, institutional and social conditions.

The article identifies these determinants based on the literature on the subject and then their analysis in relation to conditions of operation and market development of the PPP projects in the area of transport infrastructure in Poland. The analysis covered the years 2009-2018 and was conducted against the background of development of the PPP market in selected EU countries.

Keywords: determinants of public-private partnership PPP, transport, PPP in Poland

\section{Introduction}

Transport infrastructure has specific characteristics such as: service and social service character, capital intensity, long period of payback of incurred financial expenses, technical and economic indivisibility [1]. These characteristics caused that infrastructure was generally considered to be the domain of activity and financing by public authorities. However, in recent decades, economists dealing with this issue have presented a view that infrastructure is no longer perceived as public goods and should not be provided by the state only, [2-3]. Currently, it is believed that there are no goods and services that can only be provided by the private or public sector [4]. Governments entrust implementation of public services or investment tasks to private entities and the form of involvement of private investors is often a public-private partnership PPP.

However, the practice of the PPP implementation and conducted studies show that the success of a partnership requires appropriate economic, legal, institutional and social conditions [5], [6]. In addition, the latest reports of the EU institution, which has been supporting the development of the PPP for several years, have shown that the implementation of successful projects is possible with appropriate legal, institutional framework and administrative efficiency. These instruments are currently available only in a limited number of countries with many years of implementation experience [7].

The aim of the research is to analyze the determinants of implementation and level of development of the PPP projects in the area of transport infrastructure in Poland.
The subject and purpose of the research imply an analysis of the subject literature, statistical data, evaluation reports, as well as legal acts. The method of comparative analysis and analysis of cause and effect relationships have been applied, which increases the accuracy of the obtained results and conclusions formulated on this basis.

\section{Determinants of the PPP development - a literature review}

Since the subject matter of the PPP is quite well known and it has been the subject of many publications, the article omits wider considerations on the nature and forms of that partnership. Only a general definition of the PPP, based on literature studies, is provided, [8, 9]. A public-private partnership is a type of contract between a public partner and a private partner who work together to implement a project, while retaining their own goals and interests at the same time. The result of this cooperation should be lower costs of the project and a higher quality of services than in the case of their traditional financing from public funds [10]. The form of private entities' involvement in the PPP projects depends on its specificity and the individual needs of the project participants. The detailed classification of PPP forms was presented, among others, by $\mathrm{R}$. $\mathrm{Mu}$, M. de Jong and E. ten Heuvelhof [11]. Here one can only list the basic forms of participation of private entities in infrastructure projects: BOT - construction, exploitation, transfer, DBFO - design, construction, financing, exploitation and BOO construction, exploitation, ownership (ownership remains permanently in the private sector).

\section{Beata Zagozdzon}

Faculty of Transport and Electrical Engineering, Kazimierz Pulaski University of Technology and Humanities in Radom, Poland E-mail of corresponding author: b.zagozdzon@uthrad.pl 
The literature also shows that the success of a partnership requires the provision of appropriate economic, legal, institutional and social conditions (success means a PPP project that has been carried out according to budget, schedule and quality of service standards) [5], [6]. Conditions favorable for the PPP implementation are defined as critical success factors - CSF. Their identification was the subject of extensive research conducted by Harcasttle et al. [12], which identified five main groups of factors: effective purchase process, feasibility of the project, government guarantee, favourable economic conditions and available financial market. The CSF classification, which is based on various aspects of risk associated with the PPP projects, was developed by Ozdogann and Birgonul [13]. Technical, financial and economic, social, environmental, political and legal risks are important determinants considered by decision-makers. An extensive review of the CSF was also presented by $\mathrm{Ng}$ et al. [14], who studied the importance of these factors, taking into account the objectives of the public sector, private sector and society. They proposed to divide the factors into four groups: political and legal, economic and financial, technical, social.

Based on literature research, it can be assumed that the classification of the determinants of the PPP success includes the following groups of factors: economic and financial, political and legal, technical and social. In addition, they can be divided according to the level of analysis. Determinants that are shaped by the government and its institutions can be described as factors at the macro level. However, those that affect the practical implementation at the stage of project preparation and feasibility assessment concern the micro-level.

These determinants have a differentiated impact on the success of the PPP. The research conducted by Chou et al. [15] shows that at the macro level, the following have the strongest impact: stable macroeconomic conditions, economic and political support of the government, availability of financing, legal system, competent public advisory agencies, social support, clear procurement process, competition in the procurement process. For transport infrastructure projects, an important factor, emphasised by Hammami et al. [5] and Chou et al. [15], is the stable macroeconomic condition of the country, and in particular such indicators as the GDP growth, purchasing power of customers, market size. Good macroeconomic conditions, according to Mansoor and Klein [16], are able to attract investors and increase the level of financial resources. Well-organised public advisory agencies are also a key factor. Their activity is particularly important in countries that have no experience with the PPP [5].

The element of experience in implementation of projects is worth noting here. It is about the experience of the government, private investors and multilateral lenders in the field of this kind of projects. A trustworthy and experienced private consortium provides the opportunity for agreement at the stage of project preparation and its subsequent technical feasibility. The experience of financial institutions is equally important because the private sector bases its financing structure primarily on external sources. Efficient financial intermediation, free access to capital and financial services are the key factors in the success of the PPPs. Research conducted by Butkiewicz and Yanikkay [17] show that the involvement of multilateral lenders and credit agencies in the project reinforces the positive outcome of this investment.

On the other hand, micro-level factors of significant importance, according to $\mathrm{Ng}$ et al. [14], are: socially acceptable level of fees/tariffs, reliable and experienced private consortium, long-term demand for services, stability of service provision, financial attractiveness of the project for private investors and cost effectiveness of the project in comparison with traditional forms of its implementation.

\section{Analysis of the PPP functioning conditions in Poland}

Implementation of the PPP projects requires that the predefined determinants were realized, especially those at the macro level. They create a fundamental framework for the functioning of partnership, without their fulfilment the PPP formula will not exist at all, not to mention the success of investment implementation. Further, due to the synthetic character of the article, the most important conclusions from the conducted research will be presented. These conclusions were formulated in relation to the basic key factors, which are: the legal system, government support, in particular the activity of public advisory agencies and availability of financing.

Stable law and certainty of its interpretation is a key and necessary condition for implementation of the PPP. In Poland, the first act, which enabled implementation of road investments by the private sector, was drafted in 1994 . The practice of implementation showed problems and as a consequence the Act was amended - in 2000 and 2005. However, those legal actions were not enough and in 2008 a new, more flexible act was passed, which initiated the actual process of implementing public tasks in the PPP formula. In 2018, the government decided to increase the scale and effectiveness of the PPP and amended the Act of 2008 [18]. The new regulations simplify the procedure of selecting a partner and the process of concluding contracts. Moreover, they provide comprehensive advisory services for public entities and optional certification (evaluation) of projects by the minister of regional development. Legislative activities of the government have eliminated many legal obstacles. The current regulations are so flexible that even political changes will not be a barrier to the PPP implementation.

The government also plans to establish a guarantee and warranty system for the public and private sectors. It concerns the creation of a special fund for the PPP, preferential rules and interest rates [15]. The latter is very important as it will facilitate access to bank loans for investors. In previous years, external financing was provided mainly to projects that met one of two criteria: 


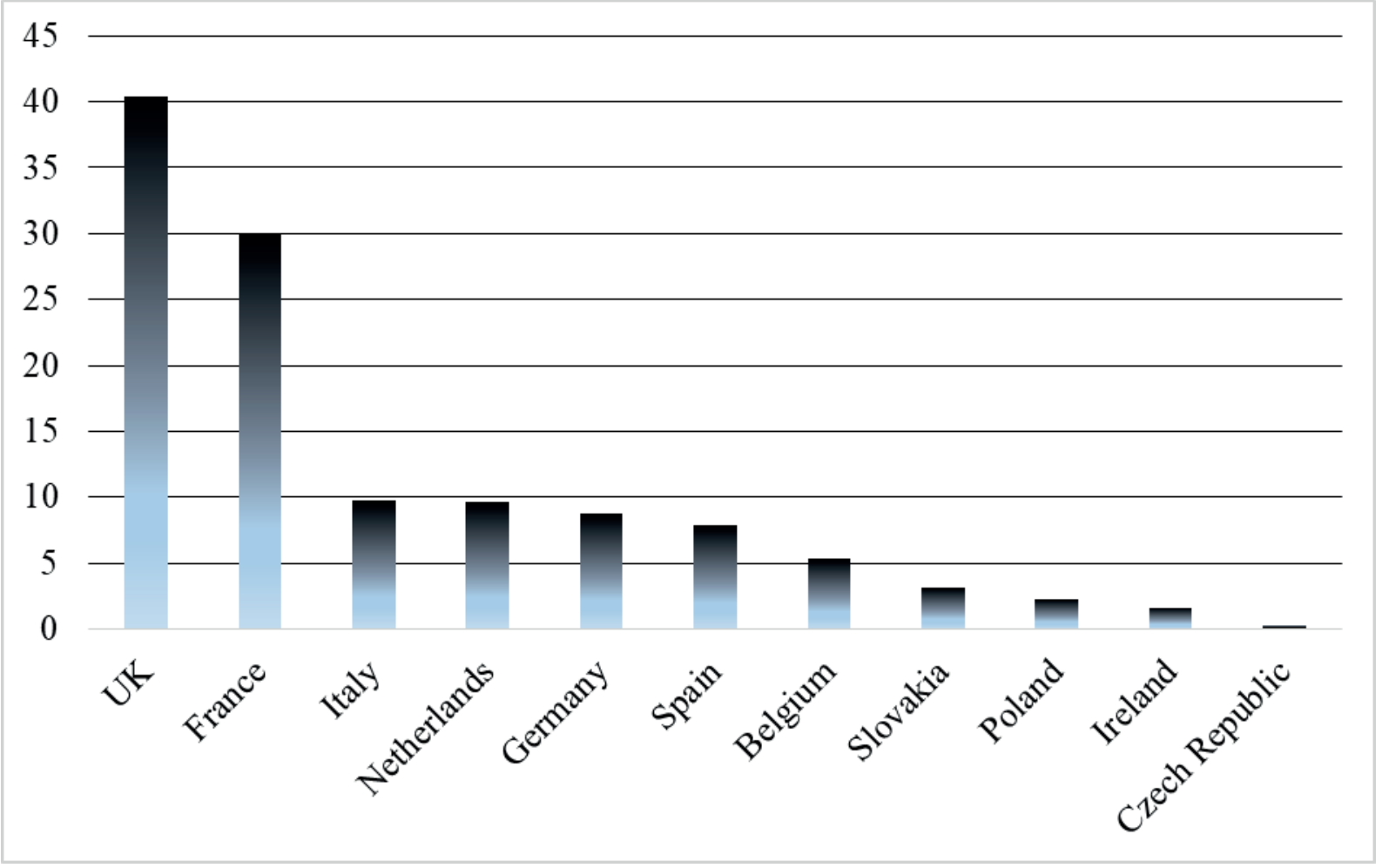

Figure 1 Total value of the PPP projects in 2009-2018, in selected EU countries (billion euro)

limited financial involvement of the public partner or a small scale of the enterprise, allowing the private partner to finance with its own contribution. The position of the banks was quite restrictive and a large part of projects did not receive financing.

Another determinant of the PPP success is availability of the public advisory institutions. In 2011, a governmental PPP Platform was established to assist in the preparation and implementation of projects. However, this initiative was not sufficient. Therefore, starting from 2017, the government intensified its activities in this area: a three-year training project was launched, in which the government and local government administration employees participate, the minister for regional development offers free legal, financial and technical advice and agreements were also signed with consortia of consulting companies to provide comprehensive advice to public entities. Moreover, the government plans to initiate 10 pilot projects by the end of 2020 .

The government expects that the effect of the above actions will be, among others, the conclusion of at least 100 new agreements by the end of 2020 and an increase in the number of signed agreements in relation to the number of announcements of choosing a private partner to $40 \%$ [18].

\section{Analysis of development of the PPP market in Poland}

While studying the level of the PPP development in Poland, it is worth considering this issue against the background of the EU project market. Figure 1 presents development of the PPP market in selected countries in the years 2009-2018, developed on the basis of research conducted by the European PPP Expertise Centre EPEC [19]. The data include large investment projects - until 2010 these were projects worth more than $5 \mathrm{~m}$ euro and since 2011 more than $10 \mathrm{~m}$ euro (the value of the so-called "financial closure" projects).

The leader of the European PPP market was and still is the United Kingdom, which since the beginning of the 1990s has used various forms of cooperation between the public and private sectors to implement investments and provide services. The partnership also has a significant place in countries such as: France, Germany, Italy, the Netherlands and Spain.

It is worth mentioning here that the most important area of the PPP implementation is transport infrastructure. Financial resources earmarked for these enterprises constituted, in the years 1995-2009, an average of 75-90\% of the total value of projects. In 2018 , their share decreased and amounted to $48 \%$ due to the growing value and number of projects in the area of telecommunications and environmental protection for several years [19].

Compared to other EU countries, the value of the market for the large PPP projects in Poland is very small and represents only $2 \%$ of the total value. This relatively low level of development of the PPP market will be the subject of further research. These included reports and statistics available on the government's PPP Platform [20].

Figure 2 shows the value and number of the PPP projects in individual years 2009-2018. Figure 3 shows the total value and number of projects by economic sectors in the entire period. These data include all the projects that have been implemented or are being currently implemented 


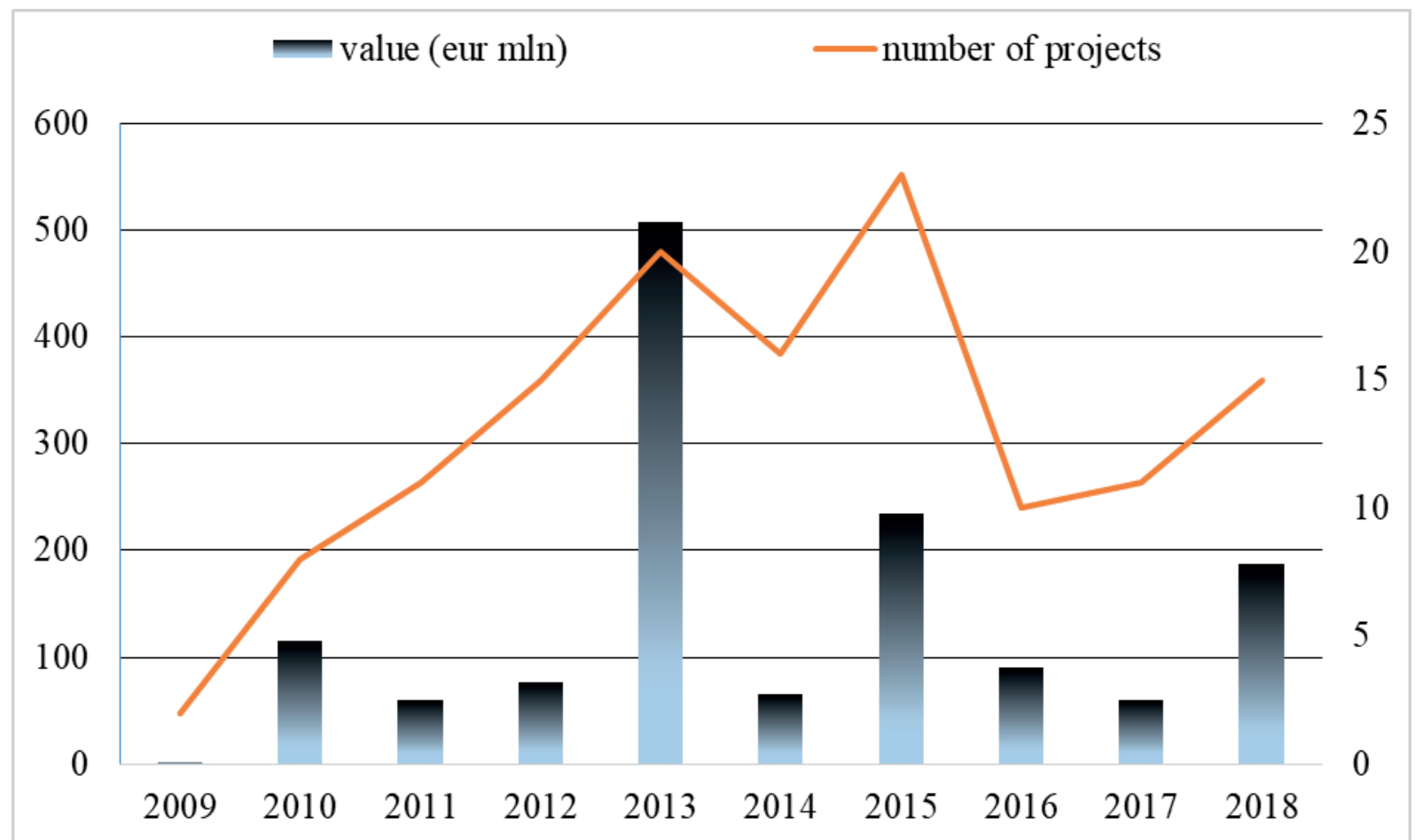

Figure 2 The PPP project market in Poland by value and number of projects (2009-2018)

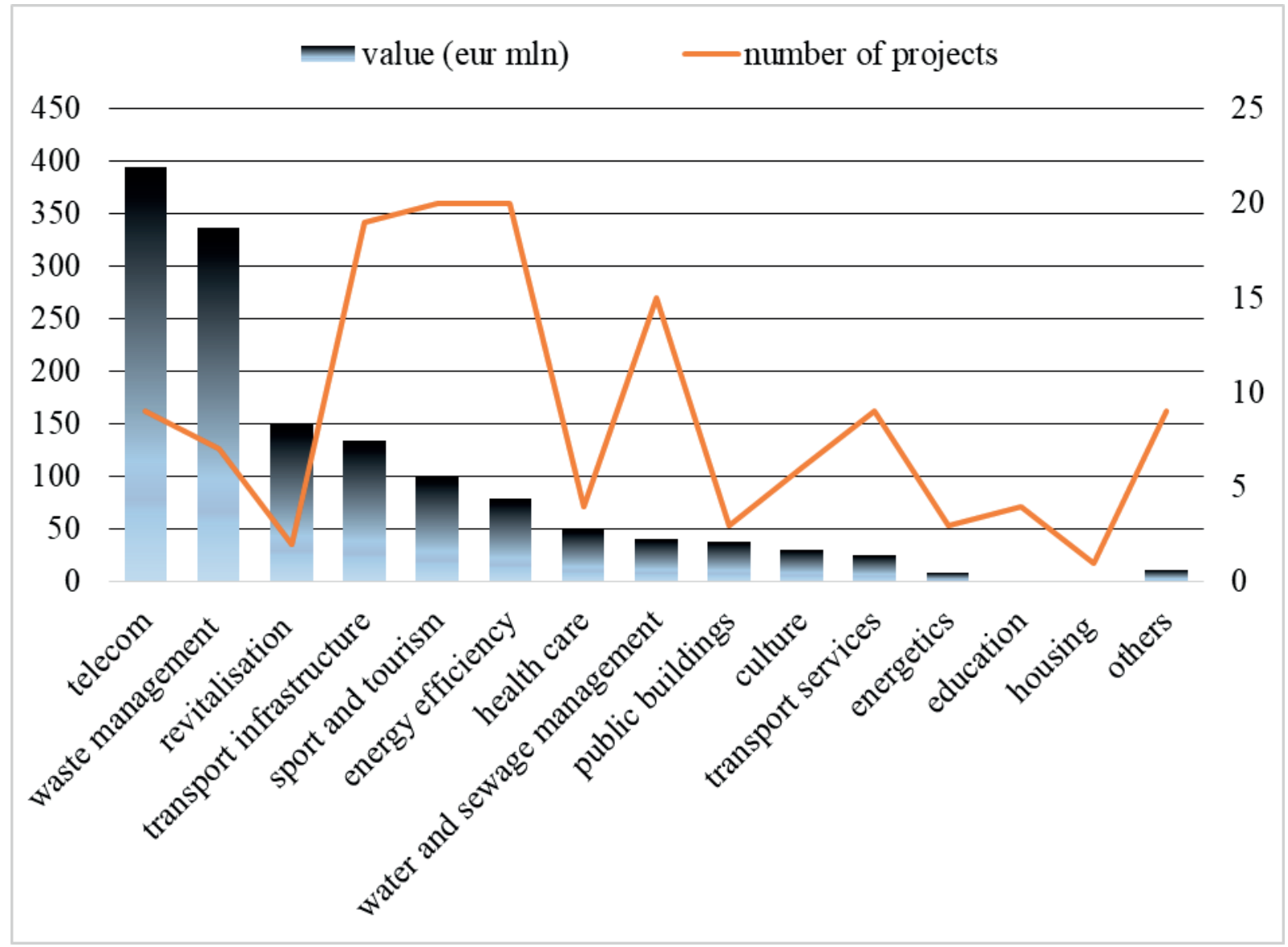

Figure 3 Total value and number of the PPP projects in Poland, by sector of economy (2009-2018)

and their value is the sum of the value of investment outlays or services, regardless of the amount of these expenditures.
The PPP project market actually started to develop in 2009 , after the change of legal regulations to more flexible ones, corresponding to the specificity of these enterprises. 
Between 2009 and 2018, 131 projects were completed and their value amounted to 1.4 bn euro. Both the value and the number of projects vary greatly from year to year. In 2013, the highest value PPP agreements were concluded, as the subject of the agreements were large investment projects, including: construction of waste incineration plant in Poznan (185m euro) or broadband network in the Mazowieckie and Podkarpackie voivodships (183m euro). However, in 2016-2017, the number of contracts and the value of projects decreased. This is a consequence of poor activity of local self-governments as entities initiating projects. This activity is a function of, among others, the level of absorption of the EU funds. An increase in use of the EU funds could have been an important factor limiting the interest of the public sector in the PPP projects. This issue will be discussed in the article.

Further analysis of the PPP market allowed to identify its features and changes that took place in the analysed period [20]:

- 131 contracts were signed and executed, and the effectiveness of the PPP proceedings, i.e. the ratio of the number of contracts signed to the number of announcements of choosing a private partner, was in 2009 - $5 \%$, whereas in $2018-32 \%$,

- the largest number of contracts concluded concerned projects with a value of up to $10 \mathrm{~m}$ euro - $72 \%$, while contracts with a value of more than $60 \mathrm{~m}$ euro accounted for only $6 \%$,

- projects are implemented mainly in the following sectors (taking into account their value): telecommunications - $27 \%$, waste management - $24 \%$, revitalisation - $10 \%$, transport infrastructure - 10\% (Figure 3),

- investment projects dominate - $58 \%$, however, there is also a large share of service projects - $42 \%$,

- 14 hybrid projects were implemented (co-financed from EU funds), which constituted only $10 \%$ of all the PPP undertakings,

- the agreements are concluded mainly by local selfgovernments - $90 \%$ of all the contracts, whereas the central government administration signed only 6 out of 131 contracts,

- among self-government authorities, the largest number of contracts were implemented by large, economically active urban agglomerations (Warsaw, Silesian agglomeration, Krakow, Wroclaw, Gdansk),

- the contribution of the public side to the project consisted in providing the property on which the private partner was to construct the infrastructure in accordance with the "land for infrastructure" principle; more than half of the projects is financed exclusively by the private partner,

- the average contract period is 21-23 years,

- the average time from the date of the project announcement to the conclusion of the contract was in 2009 - 264 days, and in 2018 - 257 days,

- among local authorities that initiate projects, some use external advisory services - in 2016 it concerned $37 \%$ of projects, while in 2018 - $54 \%$ of projects.
The PPP market in Poland can be described as a "market under construction", dominated by the low-value projects that are not included in EPEC reports. Projects are initiated by local authorities, mainly in large urban agglomerations. It is worth emphasizing that the effectiveness of the PPP proceedings has improved, the period of negotiations and preparation of contracts has been decreasing and the scope of using the services of external consulting companies has increased. Public entities, operating within the legal framework, adapted to the specificity of the PPP, gain experience in the implementation of projects. These determinants are essential for the success of projects and are an impulse for development of partnership.

When studying the value of the PPP market projects, it can be compared with local government expenditure investments. In 2009-2011, these expenditures amounted to 30.4 bn euro and the value of the PPP projects amounted to 0.18 bn euro, which was $0.06 \%$. However, in $2016-2018$ the value of projects was $1.3 \%$ in relation to investment outlays (25.3 bn euro - outlays, 0.33 bn euro - PPP projects) [21]. The government plans that the value of the PPP investments should amount to at least $5 \%$ of the public sector outlays. A comparable level - $4 \%$ of all investments in the public sector, the PPP projects constituted in 2007 in the "old" EU countries.

Turning to the analysis of the PPP projects in the area of transport infrastructure in Poland, one can distinguish the market of relatively small enterprises that initiate local governments and the market of large government projects. The first one includes mainly the construction of parking lots and bus shelters. These investments are not the basic elements of transport infrastructure, but they are the so-called point infrastructure, complementary. Their share in the total value of the PPP projects in 2009-2018 was about $10 \%$ (Figure 3). Local authorities therefore carry out transport infrastructure projects with very limited material and financial resources. This is because local authorities have at their disposal EU funds, which they can use to finance up to $85 \%$ of the investment costs and they are non-refundable. This system is more advantageous in procedural and financial terms than the PPP.

However, large projects include a programme for the construction and operation of toll motorways, launched by the government in 1996-1997. In 2000-2011, private consortia carried out the following investments in the concession system: section of the A2 motorway SwieckoKonin (255 km), section of the A1 motorway Gdansk-Torun (152 km), section of the A4 motorway Katowice-Krakow $(61 \mathrm{~km})$. Consortia have built and operate about $30 \%$ of the current motorway network in Poland [22].

Another government action was a pilot project initiated in 2013, consisting in the reconstruction and maintenance of $187 \mathrm{~km}$ of lower category roads in the Lower Silesian Voivodship. The project assumed a thorough reconstruction of $113 \mathrm{~km}$ of roads within the first four years of signing the agreement and then their maintenance. The remaining $74 \mathrm{~km}$ were planned to be covered by renovation works and current maintenance during 22 years of the agreement's 
validity. The procedure of selecting a private partner started in 2014 and the final selection of the company was to take place in July 2018. However, the offers received from two companies were so high that they exceeded the level of availability fees estimated by the self-government authorities of the voivodship several times. Therefore, a private partner was not chosen.

Currently, the government is planning to build some sections of express roads in the form of partnerships. The programme is to cover the following roads: S6 - Gdansk bypass (31 km), S6 - Szczecin bypass (50 km), S6 - Koszalin - DK 6 Bozepole Wielkie $(117 \mathrm{~km})$ and S10 - Bydgoszcz Torun $(50 \mathrm{~km})$. The private partner is to design and build roads, maintain them for 30 years and then hand them over to the public party. In return, the public side is obliged to pay a cyclical fee for accessibility [18].

\section{Conclusions}

Successful implementation of the PPP projects, especially in the area of transport infrastructure, requires specific legal and institutional conditions (activity of public advisory agencies) and availability of financing. Polish legal regulations, after 25 years of experience in the practical implementation of the PPP and legislative changes, are now flexible and adapted to the specificity of projects. In recent years, the government has clearly supported the development of partnership, what is indicated by the activity of government institutions in the area of advisory services. The first effects of these activities and accumulated experience of local authorities are already visible - more and more local authorities use advisory services and the effectiveness of announced projects is increasing. The implementation of 10 pilot projects, planned by the government, as well as creation of a guarantees and warrantees system for the public sector and private PPP partners, is also of great importance for development of partnership. Certainly, this system will facilitate access to external financing of projects.

In the area of transport infrastructure, over the last ten years, projects have been implemented mainly by local public authorities. Those were small, procedurally and financially easy investments, such as the construction of bus shelters or parking lots. On the other hand, large government projects were completed in 2011, when private consortia commissioned about $470 \mathrm{~km}$ of motorways ( $30 \%$ of the total length). Therefore, the basic system of transport infrastructure implementation is traditional public financing and the PPP formula remains an alternative and complementary model. Its practical implementation is difficult and procedurally time-consuming, which makes it unattractive for public authorities, especially when they can easily obtain the EU funds. An impulse for the PPP development may be the government's programme of construction and operation of express roads. This project will increase the experience of public authorities and institutions, which is an important success factor in the capital-intensive, multilateral transport projects.

The conducted research is a diagnostics of current macro-conditions and the level of development of the PPP market. Conclusions formulated based on the analysis may be helpful for decision-makers at various levels in the context of identifying problems in implementation of projects and striving to eliminate them and in the context of shaping the directions of the target structure of the PPP market in Poland. An important issue that may be the subject of future research is an analysis of the impact of individual determinants on the success of the PPP implementation, using statistical methods and econometric models.

\section{References}

[1] GNAP, J., KONECNY, V. Transport policy related to road transport and sustainable development. Communications Scientific Letters of the University of Zilina [online]. 2003, 5(1), p. 52-61. ISSN 1335-4205, eISSN 2585-7878. Available from: http://komunikacie.uniza.sk/index.php/communications/article/view/1339

[2] ABERLE, G. Private Verkehrswegefinanzierung: Aus Fehlern lernen - Die Ursachen der Krisen bei Betreibermodellen sind bekannt / Private financing of transport routes: learning from mistakes - the causes of the crises in operator models are known (in German). Internationales Verkehrswesen. 2005, 57. ISSN 0020-9511.

[3] QUINET, E., VICKERMAN, R. Principles of transport economics. Cheltenham UK/Northampton: Edward Elgar, MA, USA, 2004. ISBN 978-1-84064-865-2.

[4] STIGLITZ, J. E. Ekonomika sektora publicznego / Economics of public sector (in Polish). Warszawa: Wydawnictwo Naukowe PWN, 2004. ISBN 978-8-30115-187-4.

[5] HAMMAMI, M., RUHASHYANKIKO, J.F., YEHOUE, E. Determinants of public-private partnerships in infrastructure. Working Paper WP/06/99. IMF Institute, 2006.

[6] GALILEA, P., MEDDA, F. Does the political and economic context influence the success of a transport project? An analysis of transport public-private partnerships. Research in Transportation Economics [online]. 2010, 30(1), p. 102109. ISSN 0739-8859. Available from: https://doi.org/10.1016/j.retrec.2010.10.011

[7] European Court of Auditors. Public Private Partnerships in the EU: Widespread shortcomings and limited benefits. Special report [online]. 2018. Available from: https://www.eca.europa.eu 
[8] FLYVBJERG, B., BRUZELIUS, N., ROTHENGATTER, W. Megaprojects and risk: an anatomy of ambition [online]. UK: Cambridge University Press, 2003. eISBN 9781107050891. Available from: http://dx.doi.org/10.1017/CBO9781107050891

[9] DEVAPRIYA, K. A. K. Governance issues in financing public-private partnership organisations in network infrastructure industries. International Journal of Project Management [online]. 2006, 7(24), p. 557-565. ISSN 0263-7863. Available from: https://doi.org/10.1016/j.ijproman.2006.07.003

[10] OSBORNE, D., GAEBLER, T. Reinventing government - how the entrepreneurial spirit is transforming the public sector. New York: Plume, 1993. ISBN 978-0452269422.

[11] MU, R., DE JONG, M., TEN HEUVELHOF, E. A typology of strategic behaviour in PPPs for expressways: lessons from China and implications for Europe. European Journal of Transport and Infrastructure Research [online]. 2010, 10(1). ISSN 1567-7141. Available from: http://resolver.tudelft.nl/uuid:acb97116-a524-43fc-88ae-8065d25f589b

[12] HARDCASTlE, C., EDWARDS, P. J., AKINTOYE, A., LI., B. Critical success factors for PPP/PFI projects in the UK construction industry: a factory analysis approach. Public Private Partnerships e Opportunities and Challenges : proceedings. 2005, p. 75-83.

[13] OZDOGANM, I. D., BIRGONUL, M. T. A decision support framework for project sponsors in the planning stage of build-operate-transfer (BOT) projects. Construction Management and Economics [online]. 2000, 18(3), p. 343-353. ISSN 0144-6193, eISSN 1466-433X. Available from: https://doi.org/10.1080/014461900370708

[14] NG, S. T., WONG, Y. M. W., WONG, J. M. W. Factors influencing the success of PPP at feasibility stage - a tripartite comparison study in Hong Kong. Habitat International [online]. 2012, 36, p. 423-432. ISSN 0197-3975. Available from: http://dx.doi.org/10.1016/j.habitatint.2012.02.002

[15] CHOU, J.-S., TSERNG, H. P., LIN, CH., YEH, CH.-P. Critical factors and risk allocation for PPP policy: comparison between HSR and general infrastructure projects. Transport Policy [online]. 2012, 22, p. 36-48. ISSN 0967-070X, eISSN 1879-310X. Available from: http://dx.doi.org/10.1016/j.tranpol.2012.05.009

[16] MANSOOR, D., KLEIN, M. Government support to private infrastructure projects in emerging markets [online]. Washington: World Bank, 1999. Available from: https://doi.org/10.1596/1813-9450-1868

[17] BUTKIEWICZ, J., YANIKKAYA, H. The effects of IMF and World Bank lending on long-run economic growth: an empirical analysis. World Development [online]. 2005, 33(3), p. 371-391. ISSN 0305-750X. Available from: https://doi.org/10.1016/j.worlddev.2004.09.006

[18] Polityka rzadu w zakresie rozwoju partnerstwa publiczno-prywatnego. Zalacznik do uchwaly Nr 116/2017 Rady Ministrow / Government policy for the development of public-private partnerships. Annex to Resolution No. 116/2017 of the Council Ministers (in Polish). 2017.

[19] Market Update. Review of the European PPP Market in 2018 [online]. EPEC, EIB, 2019. Available from: https://data.eib.org

[20] PPP Platform [online]. Available from: https://www.ppp.gov.pl

[21] Statistical Yearbook of the Republic of Poland, 2010-2018 [online]. Warsaw: Central Statistical Office, 2010-2018. Available from: https://stat.gov.pl

[22] ZAGOZDZON, B. Determinants of implementation of public-private partnership in Poland: the case of transport infrastructure. Advances in Economics and Business [online]. 2013, 1(2), p. 57-71. ISSN 2331-5059, eISSN 2331-5075. Available from: https://doi.org/10.13189/aeb.2013.010203 